\title{
The Exploration of Ethno-Mathematics Embedded on Traditional Architecture of Rumah Gadang Minangkabau
}

\author{
Rozi Fitriza \\ Tadris Matematika \\ Fakultas Tarbiyah dan \\ Keguruan UIN IB \\ Padang, Indonesia \\ rozifitriza.mtk@gmail.com
}

\author{
Dona Afriyani \\ Tadris Matematika \\ IAIN Batusangkar \\ Tanah Datar, Indonesia \\ donaafriyani@iainbatusangkar \\ ac.id
}

\author{
Turmudi \\ Mathematics Education \\ Departmen \\ FPMIPA, UPI \\ Bandung, Indonesia \\ turmudi@upi.edu
}

\author{
Dadang Juandi \\ Mathematics Education \\ Departmen \\ UPI Bandung \\ Dadang.juandi@upi.edu
}

\begin{abstract}
Rumah gadang is a Minangkabau traditional house. Rumah gadang is a stage house where the house body is enlarged upward, like a ship. While the roof resembles a buffalo horn called gonjong. This paper describes the mathematics that is embedded in the design of rumah gadang. Exploration is done through observation in the rumah gadang, interviews with tukang tuo, adat leaders and literature studies. The results show that in rumah gadang design there are concepts of numbers, measurements and geometry. The results of this exploration will be able to help teachers to use the context of rumah gadang design in learning mathematics.
\end{abstract}

Keywords - rumah gadang architecture, ethno-mathematics

\section{INTRODUCTION}

The view that develops in today's society is that math has nothing to do with culture (culture- free). According to Turmudi (2008) that the mathematical society is the absolute perfect science with an objective truth, far from the affairs of human life. An opinion that says mathematics is knowledge that has nothing to do with culture is wrong. According to Bishop, mathematics is a form of culture. Mathematics as a form of culture in fact has been integrated in all aspects of people's lives wherever located. In essence, the math is the symbolic technology that grows on the skill or environment activity that is cultural. Thus the mathematics of a person affected by their cultural background, because all they do is based on what they see and feel (A. Bishop, 1994).

Ethno-mathematics, becomes a study that shows the interrelationships between culture and mathematics. Etnomathematics described as the intersection of the three sets of disciplines, namely: mathematics, cultural anthropology and mathematical modeling (Orey \& Rosa, 2006: 62). Mathematics in ethno-mathematics viewed as a discipline that is tied to culture and values in people's lives. According to Barton (Barton, 1996: 196) "Ethnomathematics is a field of study which examines the way people from other cultures understand, articulate, and use concepts and practices which are from their culture and which the researcher describes as mathematical". In this definition mentioned two important subjects to reveal the mathematical aspects in cultural activities through ethnomathematics. The two important subjects are researcher and people from other cultures. Researcher could be mathematicians or people who have experience about mathematics in their educational history. People from other cultures referred here are people who do not understand mathematics in the same way that researchers do (Barton, 1996: 199-200)

Culture according to Koentjaraningrat (1985: 9) is "the whole idea and the work of the man, which must be familiarized with learning, along with the whole of the result of his mind and his work" The greatest cultural element is called universal cultural element. The element of universal culture is a cultural element that can be found in all cultures in the world. The element of universal culture as well as the content of culture, is as follows (Koentjaraningrat, 1985: 2): 1) The religious system and the religious ceremony, 2) system and civil society organizations, 3) knowledge systems, 4) language, 5) art, 6) livelihood systems, 7) technology systems and equipment. These seven elements of universal culture can be subdivided into sub-elements. Sub elements can be subdivided again into sub-elements and so on, so that it can be done in a systematic assessment analysis. The composition of elements of universal culture above sequence shows the difficulty level to change.

Traditional house-shaped architecture is a form of universal culture, technology system. Based on the oxford dictionary "architecture is art and science of building; design or style of building(s).This understanding can be broader, the architecture covers all the processes of analysis and planning all the physical needs of the building, for example, organizing the design of buildings, ranging from the macro level of urban planning, urban design, landscape architecture to the micro level namely interior/exterior design, accessories design and knacks of complementary products. Architecture also refers to the results of the design process. The work of vernacular architecture recognized by acclamation and the results were tested in a relatively long period of time and very long until ingrained, was classified as a traditional architectural works. (Suharjanto, 2011, p 601). 
Rumah gadang which is a traditional house, is a form of expression of values and cultural philosophy of Minangkabau tribe. Rumah gadang is a kind of stage house that is physically large and consists of several rooms. Characteristic of rumah gadang which is very prominent is the curved shape of the roof and extended at both ends, so that when viewed from the front resembles buffalo horns called gonjong.Therefore rumah gadang is also called rumah gonjong. The construction of rumah gadang building is big upwards almost like a boat. The posts are enforced with a slope of $91^{\circ}-94^{\circ}$, where the shape of the post is prism facet-n. The size of rumah gadang is determined by the amount of room (long section) and lanjar (wide section). Ethno-mathematics studies in the context of traditional houses have been done by M. Putrietis (2014) on traditional houses of indigenous villages of Kuta Ciamis, Seroto (2012) in the traditional houses of Limpopo Province and D.B. Soares (2009), explores geometric concepts in Mozambique's traditional house. The study of architecture and mathematics (geometry, proportion, and symmetry) on the architecture of Palladio's Villas, the transformation geometry of the Central European Baroque Church, fractal geometry at The Palmer House and others (K.Williams\&M.J.Ostwald, 2015).

\section{RESEARCH Methodology}

This study used a qualitative research approach. A qualitative approach was used to reveal ethno mathematics contained in the rumah gadang Minangkabau. A qualitative approach by J.Creswell (2009) is a research process conducted in a natural background for understanding social issues, information is presented clearly with a thorough and complex depiction by using words. The research method used is ethnography method. The ethnographic method according to Wolcott $(1975,1982)$ is "involves the suspension of one's own judge-ment that is based in one's own cultural assumptions and demands that one look through the eyes of those who are themselves the members of the culture under scrutiny" (R.Teppo, 1998: 82). This research was conducted in three Luhak (the community which is a combination of several villages) known as Luhak nan Tigo, which includes: Luhak Tanah Datar, centered on Batusangkar; Luhak Agam, centered on Bukit Tinggi and Luhak Limapuluh Kota, centered in Payakumbuh (Soeroto, 2005, p.4) (Syamsidar, 1991, p.17). Data collection in this study using techniques: observation, interviews, document analysis and artifacts. Observations made to observe the architecture and ornaments of rumah gadang to further revealed the mathematical ideas embedded in the building. Implementation of observation using photo and video recording. Interviews were conducted on research informants consisting of tukang tuo, traditional architecture experts and ninik mamak, as adat stakeholders who know the customs or philosophy rumah gadang. In this study the documents collected are the writings about the philosophy of traditional house Minangkabau (tambo), drawing plans rumah gadang building the results of cultural studies or traditional builders. Artifacts that become the object is rumah gadang which representative characterize traditional house of Luhak nan Tigo area.

As a field of study, ethno-mathematics is defined as a cultural anthropology of mathematics and mathematics education (P.Gerdes, 1996: 915). From the mathematical point of view, the success of ethno-mathematics studies depends on how to model reality. But it does not cause the researcher to not responsible of research process of the culture (anthropology). In other words, ethno mathematics researchers can only understand to what is found if using a mathematical and cultural point of view.

Mathematical analysis contained in the rumah gadang design uses four areas of mathematical studies, namely: number, measurement, geometry, and logic (A.J.Bishop, 1997: 22). Furthermore, Bishop divides the four areas into six mathematical activities that can be seen from a culture, namely counting, locating, measuring, designing, playing and explaining.

\section{FINDINGS AND DISCUSSION}

Rumah gadang which is become the object of observation is rumah gadang that still has the characteristics of traditional architecture. In general, rumah gadang was observed at least 100 years old. For Luhak Tanah Datar starts from rumah gadang in Pariangan village which is believed to be the origin of the ancestors of the Minangkabau tribe, rumah gadang kampai nan panjang in Balimbing village that has been aged more than 350 years. For Luhak Agam in Sungai Janiah and Tilatang Kamang and Koto nan gadang and Balubus for Luhak 50 kota.

The size used in the construction of a rumah gadang is anthropometric, where the unit of measure is based on the size of the human body. The unit of measure used eto (cubit), dapo (fathom), tampok or finger. This measure is taken from the size of bundo kanduang (the oldest woman in the rumah gadang) body parts or the size of tukang tuo. For example, a rumah gadang with a length of 21 eto and width of 14 eto. The use of the tampok and fingers for example on the length of the room, 3 eto 1 tampok and 3 fingers. The use of non-standard size units in measurement is used before humans know the standard unit. Measurements is one of the principles of math application in everyday life. Measurements connect between geometry and real numbers, which use the concept of numbers in practical activities, When students learn estimation and measurement using non-standard units, they simultaneously see the weakness of the use of non-standard units, so that they understand why the required standard unit (A.Janet, 1991.70).

Some tukang tuo believe in tajuruba science in determining the size of the house. The following interview results of researchers with tukang tuo:

Researcher: How is an example of the use of tajuruba, Sir?

Tukang tuo: Suppose the length of the house is 18 eto, width 12 eto, height 8 eto. If summed all the sizes are 38 eto. This is not allowed, because the number of length, width and height is even.

Researcher: Why not be allowed, Sir? 
Tukang tuo: If the number of length, width and height of a house is even, the house is not good to live in. Furthermore the amount of the size was reduced by 35 eto, i.e 38 eto -35 eto $=3$ eto.

Researcher: Why reduced by 35 eto, why not 37 eto?

Tukang tuo: Because 35 can be divided into 5, 37 cannot be divided. So for the size of length, width and height, exaggerated or reduced not exceed 3 eto.

Based on the interview above it shows that tukang tuo has understood the concept of prime number is 37 , and the cardinal numbers, is 35. Tukang tuo also simultaneously use the approximation skills in measurement.

In principle the rumah gadang is built on tribal land extending from north to south, its bumbungan (horizontal wood of roof) is facing Marapi mountain. This is because a belief that the origin of the Minangkabau ancestors is from the slopes of Mount Marapi, Pariangan. Before the entry of Islam to Minangkabau megalithic culture also influence the direction of the construction of rumah gadang. Mount Marapi is believed as a magical mountain, so rumah gadang is built extending to the mountain of Marapi. as a form of worship. In nagari Batipuh, Tanah Datar sleeping position in the rumah gadang was arranged, the direction is called manggantang padi. Where sleeping position between the mountain of Marapi and Qibla direction, as shown fig. 1 below (Asri, 2004: 172):

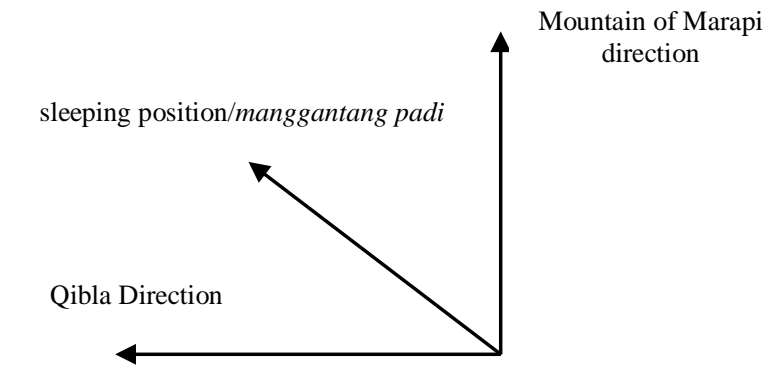

Fig. 1. Sleeping position in the rumah gadang

Pinxten reveals spatial concepts in cultures elaborated into 3 levels: physical space/object space, sosio geographical space and cosmological space. Pinxten argues that each culture has a specific way of representing world. It could be orientation toward the sun, moon and more (A.J.Bishop, 1997: 28-29). Bishop (1997) stresses that in locating ideas, the knowledge of landscape is related to the myth and history of a society's landscape.

Rumah gadang in Luhak nan Tigo is also known as bagonjong house. This is because the roof of rumah gadangshaped gonjong. In general, rumah gadang has at least 4 pieces of gonjong, which symbolize the natural elements. There are also 5 gonjong (Luhak 50 kota) and 6 gonjong. Based on the curvature of gonjong, rumah gadang is categorized to three: bulan sahari (a day moon), rabuang mambasuik (bamboo shoot stick), sapik kalo (scorpion clasp). If each gonjong form is described in a circle, it is obtained as fig. 2 follows: (Asri, 2016)

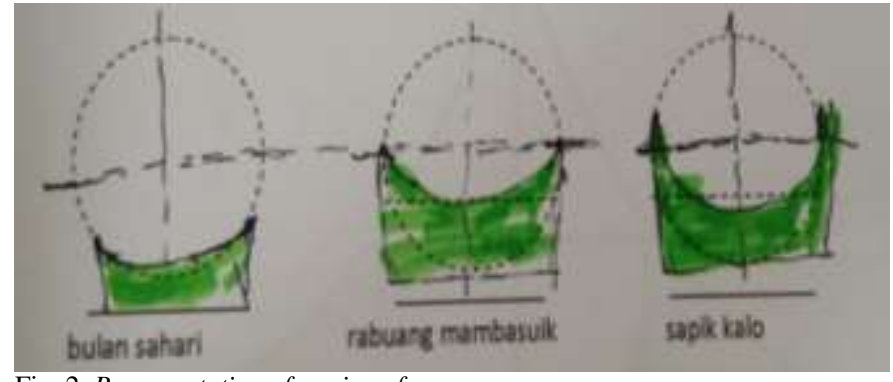

Fig. 2. Representation of gonjong forms

The number of rooms/biliak of a rumah gadang in general is odd; $3,5,7,9$. The length of the room of a rumah gadang is not always the same. Sometimes the length of the room getting to the tip enlarges or decreases. Based on the length of room, the rumah gadang is divided into 2 namely: rumah gadang pancuang talang and rumah gadang rueh tabu. (Tukangtuo, 2016). Rumah gadang pancuang talang in fig. 3, the length of room is formulated as follows:

$$
\begin{aligned}
& \mathrm{R}_{1}=\mathrm{R}-\mathrm{d}_{\mathrm{t}} \\
& \mathrm{R}_{2}=\mathrm{R}-\mathrm{d}_{\mathrm{t}}-\text { satampok, }
\end{aligned}
$$

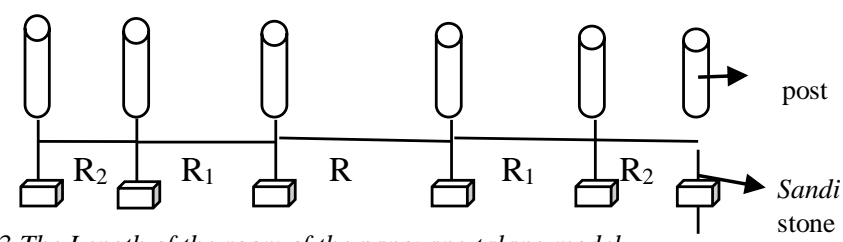

Fig. 3.The Length of the room of the pancuang talang model.

Rumah gadang rueh tabu in fig. 4, the length of the room is formulated as fig.4 follows:

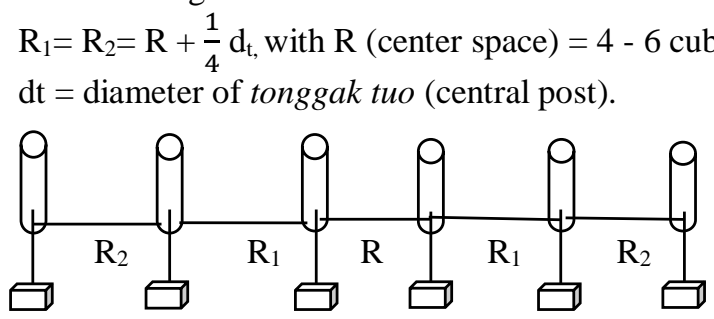

Fig. 4.The Length of the Space of the rueh tabu.

While the number of lanjar according to the principle of origin area is as much as 4 pieces; biliak, bandua, labuah and balai. Rumah gadang in Luhak Agam and Luhak 50 kota mostly have 3 lanjar. The size of the lanjar is also not always the same length (fig.5). Type of rumah gadang gajah maharam and rumah gadang sitinjau lauik, besides different from the shape of its gonjong, also differ in the length of the lanjar. Based on information from tukang tuo, the lanjar size of each type of rumah gadang as follows:

Gajah maharam type, $\mathrm{B}=\mathrm{B}$ andua $=\mathrm{Labuah}=\mathrm{A}+\mathrm{d}_{\mathrm{t}}$

Sitinjau lauik type, $\mathrm{B}=\mathrm{B}$ andua $=$ Labuah $\mathrm{A}-\mathrm{d}_{\mathrm{t}}$

With $\mathrm{A}=$ Biliak $=$ Balai $=3-5$ cubits

$\mathrm{d}_{\mathrm{t}}=$ tonggak tuo diameter. 


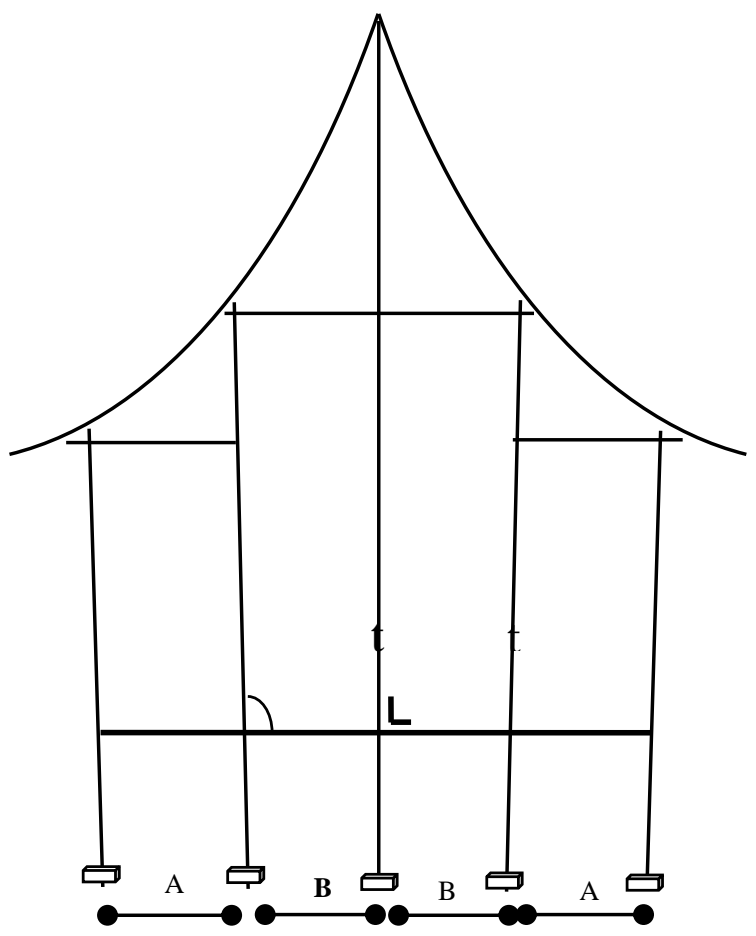

Fig. 5. The pieces of rumah gadang in width

To shape the arch of roof that suitable to alua jo patuik, the upper and lower paran parts are also curved, resulting in outer milestone (according to the long direction) not having the same height, as shown fig. 6 below:

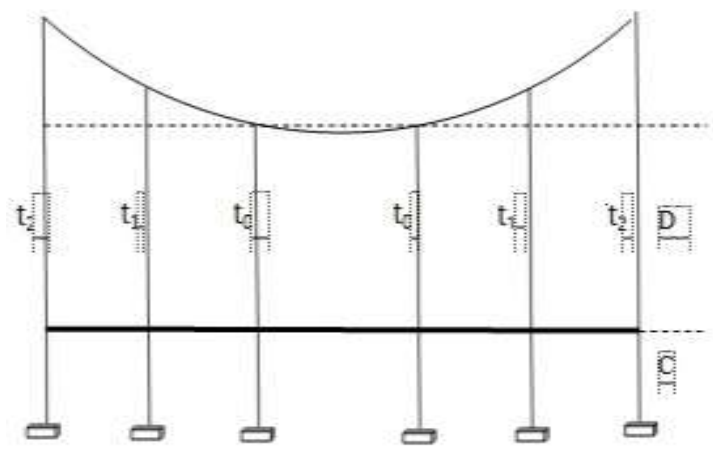

Fig.6. The pieces of rumah gadang in long direction

$$
\text { Where } \begin{aligned}
\mathrm{t}_{0} & =\mathrm{C}+\mathrm{D} \\
\mathrm{t}_{1} & =\mathrm{t}_{0}+1 / 6 \mathrm{~d}_{\mathrm{t}} \\
\mathrm{t}_{2} & =\mathrm{t}_{0}+1 / 5 \mathrm{~d}_{\mathrm{t}}+\text { satampok }
\end{aligned}
$$

The various mathematical representations above show the relationship between numbers, algebra, geometry and other mathematical aspects. Physical representation for numbers such as symbols, words, images, objects and motion is a mathematical communication tool. Where it reveal the thoughts and calculations of a person's mathematical ideas to be conveyed. This representation explains ideas that will support reasoning and build one's understanding. This representation will also enable the development of efficient algorithms for basics of operation (Kilpatrick.et.al, 2001.94).

The position of the line segments at rumah gadang, namely intersection and parallel. The posts house are parallel to each other. While the position of the post and rasuak/palanca intersect each other perpendicularly (fig.7a). Arrangement of lae with lae and kasau with kasau shows parallel line segments (fig.7b). The kasau mounted in a rumah gadang are an odd number $(21,23.25$ pieces). Installation of lae, with distance about 3 fingers.
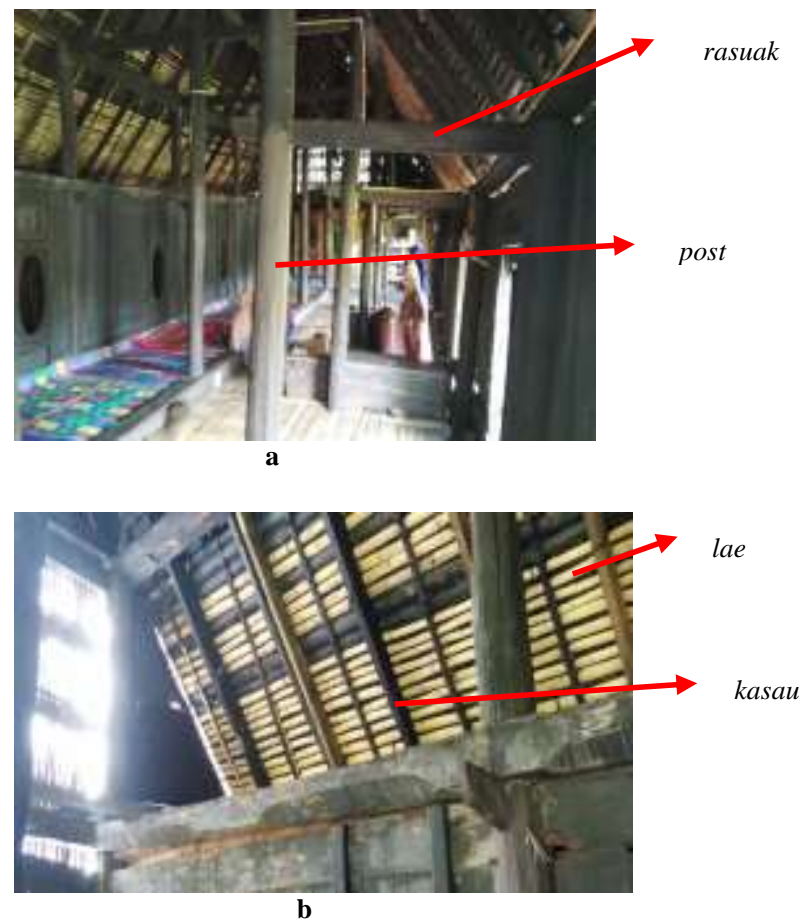

Fig.7.a. The position of post and rasuak, b. Arrangement of lae with lae and kasau with kasau

The post shape of rumah gadang is prism facet-n, Most posts surface are shaped in facet- 8 and facet-12. The outside post of rumah gadang does not stand perpendicularly, but tilted outward to a maximum of $94^{\circ}$ resulted in a slope also on the wall. The slope of the milestones toward the edge of the building parallel to the outer side, very useful to strengthen the peg system on the building wall. The angle measuring instrument that used is called apik kawa, where the tool is made of bamboo which is cut into three parts, as fig. 8 follows:

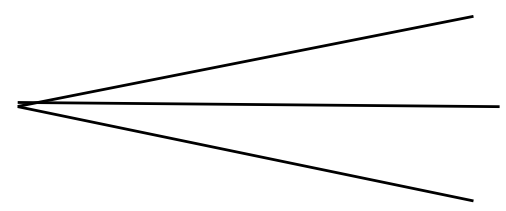

Fig. 8.Angle measuring instrument apik kawa

The height of the window is made as tall as an adult sitting, so it possible to look directly out of the house. Number of stairs at rumah gadang must be odd, i.e 5, 7 or 9 steps. It is closely 
related to the functions under the house to raise chickens, goats or cows. The harmony and functioning of each part of the rumah gadang is very important. This shown how traditional craftsman transform what they want to symbolize in the architectural form. The number of steps must be odd, this is due to the belief in the principle in life which consists of: step, sustenance, meeting and death. So if the number of stairs 4 , then it is believed that the inhabitants of the house will quickly face death.

The ornament according to John Firtz Maurice Miles is something added aesthetically to the shape or function of an object. Decorative variety has no relation with construction, ornament can be painting or decorative carving (A.M. Yosef.Dt.Garang, 1983: 46). Ornaments are any decoration or other geometric style. Here are the ornaments in the rumah gadang.

In Fig. 8a.seen decoration at the end of the post in the form of carving leaf strands. In this ornament seen the principle of symmetry, where the symmetry axis is the bone of the leaf. While in Fig. 8b, seen the sides- 8 that surrounds the post.
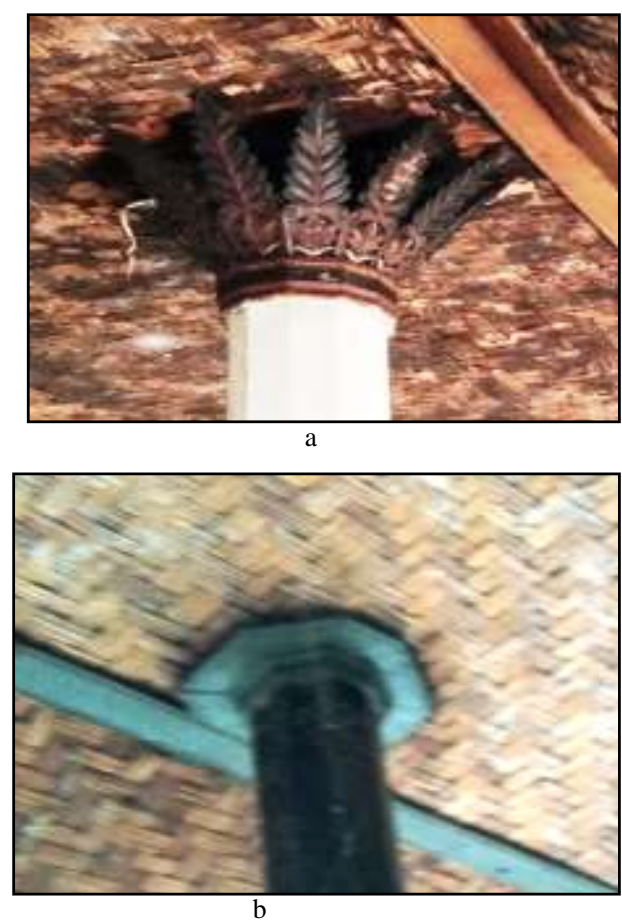

Fig 9. The frosting at the end of the post

The decorative door of this cubicle is a 2-D, i.e rectangle, circles and elips (Fig. 9a), whereas the cubicle door of rumah gadang kampai nan panjang that has been aged more than 350 years has elliptical shape with the similar rhombuses decorations (Fig.9b).

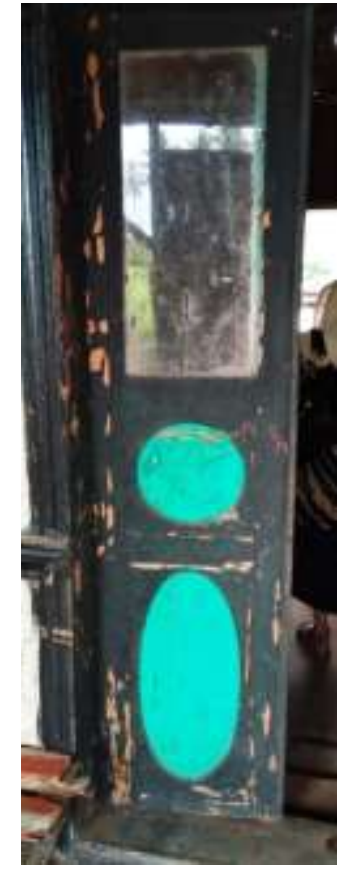

a

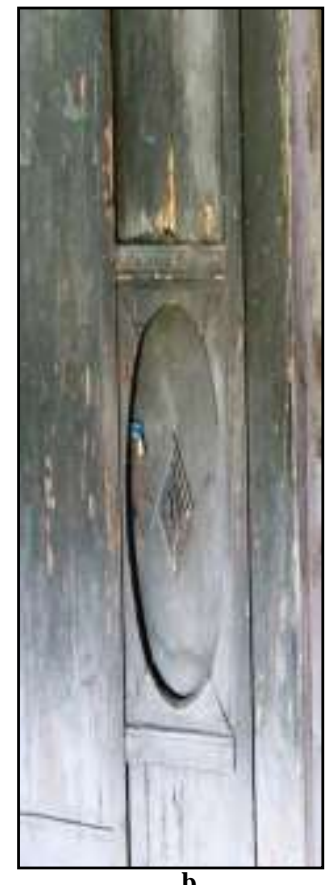

b
Fig 10. The cubicle door

In fig. 10a there are rhombus arranged on each part as much as 3 pieces. On top of it there is a structure of two dimensional figure with 2 rectangle and 1 square pattern. The harmony between the shape of the window and the underside of the house, which are equally semicircular (fig. 10b).
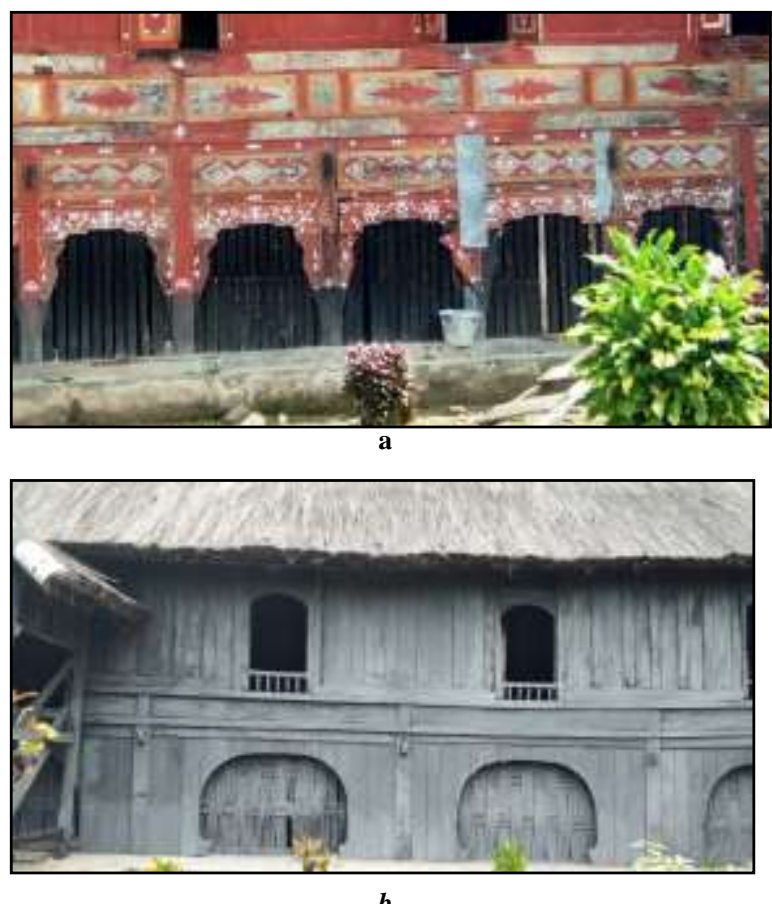

Fig 11. Home front ornament

The most prominent ornament in the rumah gadang is carving. Minangkabau carving motifs are generally derived from the philosophy of 'alam takambang jadi guru'. The natural forms used as carving motifs are not expressed naturally or realistically, but the form is distilled (changing the shape 
without abandoning the original form) in such a way that it becomes a decorative form. Naturalis sculpture has not been used in Minangkabau since the entry of Islam. Motif of carving comes from the name of plants, animals, objects, people or conditions that occur in the community. According to Ibenzani Usman, the placement of carving motifs on rumah gadang contain three parts: the motif of a large field filler, small field and large field motif that loose and free of function. (Hasni, 1999, p.11). Here are some carvings on the rumah gadang and mathematical concepts contained in it.
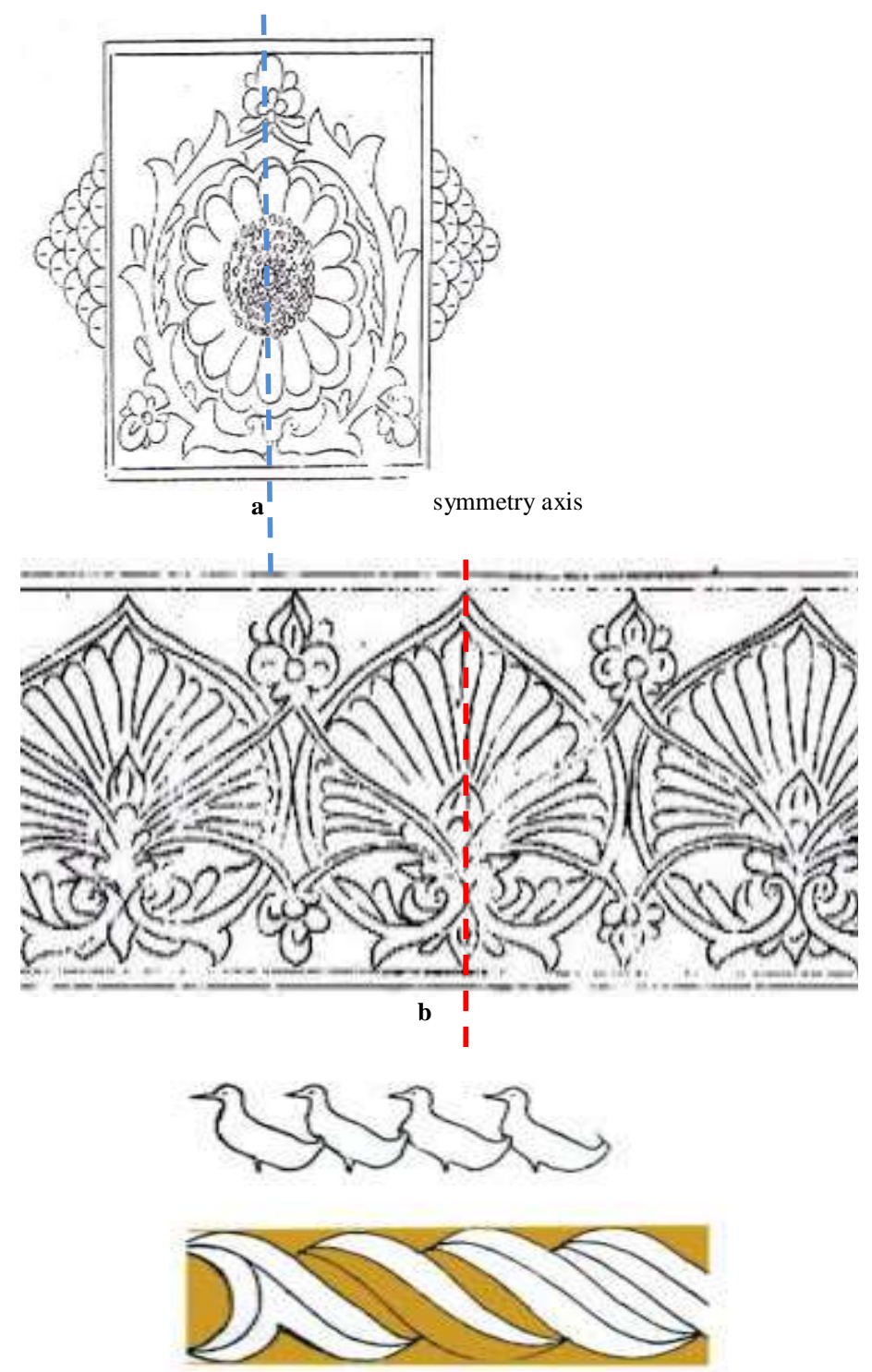

c. transformation from itik (duck) shape to itiak pulang patang motif

Fig 12. Carving on the Rumah Gadang

The carvings of the rumah gadang are seen using the concept of symmetry (Fig. 11a, 11b). In addition, many repetition of the motif is called tessellation which is one of visual objects and graphics in mathematics. Tessellation was discovered by Voronoi and is known as Voronoi tessellation: "we are given a set of points $S$ in the plane, which are the
Voronoi sites. Each site s has a Voronoi cell, also called a Dirichlet cell, $V(s)$ consisting of all points closer to s than to any other site. The segments of the Voronoi diagram are all the points in the plane that are equidistant to the two nearest sites. The Voronoi nodes are the points equidistant to three (or more) sites". Fig. $11 \mathrm{~b}$ and $11 \mathrm{c}$ use the principle of tessellation. The transformation from the real object to the carving motif is also commonly found in the carvings of rumah gadang, one of them as shown in Fig. 11c. An important part of designing is to transform parts of nature and model it into something, which allows to eliminate unimportant parts, "designing concerns abstracting a shape from the natural environment" (A.J.Bishop, 1997: 39).

\section{CONCLUSION}

Rumah gadang is the result of monumental culture of Minangkabau tribe. Rumah gadang is born from the process of transforming what they want to symbolize to the form of architectural geometry. The traditional architecture of rumah gadang involves a high-level thinking process which resulting a design that harmonizes with nature in accordance with the philosophy and needs of the Minangkabau community. The results of the study showed that in the design of rumah gadang there are concepts of numbers, measurements and geometry. The next researcher might be able to find other mathematical ideas on the rumah gadang design. Ethno-mathematics provide an opportunity for students to learn mathematics and culture at the same time. So that learning with the ethno-mathematics approach make a fun learning atmosphere while preserving the culture of the nation.

\section{REFERENCES}

[1] A.J.Bishop, Mathematical enculturation: a cultural perspective on mathematics education. The Netherlands: Kluwer Academic Publisher, 1997.

[2] A.Janet, Is there any mathematics in measurement? Teaching and learning school mathematics, 69-76, 1991.

[3] A.M. Yosef.Dt.Garang, d. Pengetahuan ragam hias minangkaba, Jakarta: Depdikbud, 1983.

[4] Asri, S, Arsitektur Rumah Adat Minangkabau (Proses Membangun Rumah Adat), pp. 1-10, 2016.

[5] Asri, S, Prinsip-prinsip pembinaan rumah adat minangkabau, Malaysia: tesis doktor falsafah Fakulti Alam Bina Iniversiti Teknologi Malaysia, 2004.

[6] Hasni, S, Ukiran Tradisional Minangkabau, Padang: Depdikbud, Direktorat Jenderal Kebudayaan, 1999.

[7] J.Creswell, Research Design: Qualitative, Quantitative, and Mixed Methods Approaches, 3rd Edition. Los Angeles: SAGE Publications, Inc, 2009.

[8] K.Williams\&M.J.Ostwald, Architecture and mathematics from antiquity to the future. Switzerland: Springer International Publisher, 2015.

[9] Kilpatrick.et.al, Adding It up helping children learn mathematics, USA: National Academy Press, 2001.

[10] P.Gerdes, Ethnomathematics and mathematics education, Springer, 1996.

[11] Putrietis, M. Study Ethnomathematics: Mengungkap Konsep-konsep Matematika Pada Aturan Adat dalam Aktivitas Pembangunan Rumah Tradisional Masyarakat Kampung Adat Kampung Kuta Kabupaten Ciamis Jawa Barat. Universitas Pendidikan Indonesia: Skripsi. 2014. 
[12] Soeroto, M. Pustaka Budaya dan Arsitektur: Minangkabau. Jakarta: Myrtle Publishing. 2005.

[13] Suharjanto, G. Membandingkan Istilah Arsitektur Tradisional Versus Arsitektur Vernakular: Studi Kasus Bangunan Minangkabau dan Bangunan Bali. ComTech Vol. 2 No.2 , 592-602, 2011.

[14] Syamsidar, Arsitektur Tradisional Daerah Sumatera Bara,. Jakarta: Depdikbud, Direktorat Jendral Kebudayaan Direktorat sejarah dan Nilai Tradisional Proyek Inventarisasi dan Pembinaan Nilai-nilai Budaya, 1991.

[15] Tukangtuo, Ruang di Rumah Gadang, (Peneliti, Interviewer), Agustus 2016.

[16] Turmudi, Landasan Filsafat dan Teori Pembelajaran Matematika Berparadigma Eksploratif dan Investigati,. Jakarta: Leuser Cipta Pustaka, 2008. 